\author{
Alina Walenia \\ Uniwersytet Rzeszowski \\ e-mail: alinawalenia@poczta.onet.pl \\ ORCID: 0000-0003-3389-9465
}

\title{
NADUŻYCIA FINANSOWE W OBSZARZE POLITYKI SPÓJNOŚCI A OCHRONA INTERESÓW BUDŻETOWYCH UNII EUROPEJSKIEJ
}

DOI: $10.15611 / \mathrm{pn} .2020 .11 .09$

Jel Classification: M12, M14

(C)2020 Alina Walenia

Praca opublikowana na licencji Creative Commons Uznanie autorstwa-Na tych samych warunkach 4.0 Międzynarodowe (CC BY-SA 4.0). Skrócona treść licencji na https://creativecommons.org/licenses/by-sa/4.0/deed.pl

Cytuj jako: Walenia, A. (2020). Nadużycia finansowe w obszarze polityki spójności a ochrona interesów budżetowych Unii Europejskiej. Prace Naukowe Uniwersytetu Ekonomicznego we Wroctawiu, 64(11).

Streszczenie: Celem artykułu jest ocena zakresu oraz metod wykrywania nadużyć finansowych w procesie wykorzystania środków z budżetu UE przeznaczonych na politykę spójności w Polsce. W artykule przedstawione zostały uwarunkowania organizacyjno-prawne dotyczące zarządzania środkami unijnymi, wdrażane w państwach członkowskich UE, mające na celu ograniczanie występujących nieprawidłowości w ich wykorzystaniu. Nadużycia finansowe wywierają szkodliwy wpływ na przychody i wydatki budżetu ogólnego UE, mogą skutkować wykorzystaniem tych środków na inne nieuzasadnione cele, a przez to ograniczać skuteczność działań UE w ustalonych obszarach. Kolejne perspektywy wdrażania środków unijnych wskazują, iż nawet najlepiej opracowane procedury kontroli nie wyeliminują ryzyka występowania nadużyć finansowych. Opierając się na danych empirycznych, zidentyfikowano skalę i przyczyny występujących nieprawidłowości w wykorzystaniu środków UE z przeznaczeniem na politykę spójności w Polsce.

Słowa kluczowe: polityka spójności, środki UE, nadużycia finansowe, interes finansowy UE.

\section{Wstęp}

W prawie Unii Europejskiej (UE) nadużycie finansowe jest zdefiniowane jako umyślne naruszenie przepisów, które powoduje - lub może spowodować - szkodę w budżecie UE. Za zwalczanie nadużyć finansowych i wszelkich innych nielegal- 
nych działań - takich jak korupcja - naruszających interesy finansowe UE odpowiadają wspólnie UE i państwa członkowskie. Nadużycia finansowe, określane jako oszustwa finansowe oraz przestępstwa przeciwko interesom finansowym UE, zdefiniowane zostały w Konwencji o ochronie interesów finansowych Wspólnot Europejskich z 26 lipca 1995 r. ${ }^{1} \mathrm{~W}$ polskim systemie prawnym tego typu nieprawidłowości traktowane są jak przestępstwa. Nadużycia finansowe jako zjawiska szkodliwe społecznie mają wpływ na budżet UE i mogą skutkować wykorzystaniem środków na inne nieuzasadnione cele, a przez to ograniczać skuteczność działań UE w obszarze polityki spójności. Powstawanie nadużyć podaje w wątpliwość uczciwość działań UE i podważa zaufanie społeczeństwa do jej polityki. W latach 2013-2017 Komisja Europejska i państwa członkowskie wykryły ok. 4,1 tys. nieprawidłowości będących nadużyciami finansowymi. Nieprawidłowości w łącznej kwocie ok. 1,5 mld euro dotyczyły unijnego wsparcia finansowego państw członkowskich, przy czym $73 \%$ nieprawidłowo wydatkowanych środków było związanych z polityką spójności $\mathrm{UE}^{2}$. Za przeciwdziałanie i podejmowanie skutecznych środków na rzecz zwalczania nadużyć finansowych w tym obszarze, $\mathrm{z}$ uwzględnieniem stwierdzonych rodzajów ryzyka, odpowiadają instytucje zarządzające w państwach członkowskich. Instytucje zarządzające to wyodrębnione podmioty, głównie sektora publicznego, które przygotowują procedury monitorowania i oceny wykorzystania środków UE, zapobiegania i wykrywania nadużyć finansowych. Działania instytucji zarządzających obejmują cały proces zarządzania zwalczaniem nadużyć finansowych, tj. zapobieganie, wykrywanie i reagowanie, w tym zgłaszanie wykrytych przypadków nadużyć i odzyskiwanie środków nienależnie wypłaconych. Instytucje zarządzające opracowują procedury zwalczania nadużyć finansowych, dokonują oceny ryzyka, a także wdrażają odpowiednie środki zapobiegania nadużyciom i ich wykrywania. Zadaniem instytucji zarządzających jest także informowanie organów dochodzeniowych i organów ścigania o podejrzeniach popełnienia nadużycia finansowego w zakresie środków UE. Wskaźnik wykrytych nadużyć finansowych w stosunku do kwoty wsparcia finansowego udzielonego w ramach polityki spójności w latach 2007-2013 wynosił od 0\% do 2,1\%, w zależności od państwa członkowskiego. W Polsce zgłoszone i wykryte nadużycia finansowe stanowiły $0,61 \%$ środków przekazanych przez Komisję Europejską z przeznaczeniem na politykę spójności. Wiele badań wskazuje, że do kategorii najczęstszych błędów popełnianych przez benefi-

\footnotetext{
${ }^{1}$ Konwencja o ochronie interesów finansowych Wspólnot Europejskich sporządzona w Brukseli dnia 26 lipca 1995 r.; Protokół do Konwencji o ochronie interesów finansowych Wspólnot Europejskich z dnia 26 lipca 1995 r., sporządzony w Dublinie dnia 27 września 1996 r.; Protokół w sprawie interpretacji w trybie orzeczenia wstępnego przez Trybunał Sprawiedliwości Wspólnot Europejskich Konwencji o ochronie interesów finansowych Wspólnot Europejskich z dnia 26 lipca 1995 r., sporządzony w Brukseli dnia 29 listopada 1996 r. oraz Drugi Protokół do Konwencji o ochronie interesów finansowych Wspólnot Europejskich sporządzony w Brukseli dnia 19 czerwca 1997 r. (Dz.U. 2009, nr 208, poz. 1603).

${ }^{2}$ Europejski Trybunał Obrachunkowy, Sprawozdanie specjalne nr 6/2019 - Zwalczanie nadużyć finansowych w wydatkowaniu środków UE w obszarze spójności, op.europa.eu/ (odczyt: 22.02.2020).
} 
cjentów w trakcie realizacji projektów należy niewłaściwe stosowanie przepisów dotyczących zamówień publicznych. W audytach przeprowadzonych w latach 2006-2019 wskazywano, iż 41\% nieprawidłowości w realizacji projektów współfinansowanych ze środków Europejskiego Funduszu Rozwoju Regionalnego oraz Funduszu Spójności spowodowane było niewłaściwym stosowaniem przepisów o zamówieniach publicznych ${ }^{3}$. W aktualnie obowiązującym stanie prawnym w Polsce w świetle ustawy z dnia 27 sierpnia 2009 r. o finansach publicznych ${ }^{4}$ środkami publicznymi są środki pochodzące z budżetu Unii Europejskiej oraz niepodlegające zwrotowi środki z pomocy udzielanej przez państwa członkowskie Europejskiego Porozumienia o Wolnym Handlu (EFTA). Uznanie statusu środków przyznanej pomocy z budżetu UE za środki publiczne ułatwia odzyskiwanie tych należności, a także stosowanie sankcji w związku z nieprawidłowym ich wykorzystaniem.

Celem artykułu jest ocena skali i zakresu niekorzystnego zjawiska nadużyć finansowych w procesie wykorzystania środków z budżetu UE w Polsce i w państwach członkowskich. W artykule przedstawione zostały obowiązujące regulacje prawne w UE i w Polsce mające na celu zapewnienie ochrony interesów finansowych budżetu UE. Analiza materiału empirycznego umożliwiła identyfikację nadużyć finansowych środków UE oraz metod ich wykrywania w Polsce, a także ocenę tego zjawiska w UE.

\section{Nadużycia finansowe w wykorzystaniu środków z budżetu UE}

Podstawę unijnej polityki spójności stanowią trzy spośród europejskich funduszy strukturalnych i inwestycyjnych ${ }^{5}$ (EFSI): Europejski Fundusz Rozwoju Regionalnego (EFRR), Fundusz Spójności i Europejski Fundusz Społeczny (EFS), określane wspólnie mianem funduszy polityki spójności UE. Komisja Europejska i państwa członkowskie wdrażają je wspólnie za pomocą programów operacyjnych (PO), które szczegółowo określają sposób, w jaki państwa członkowskie będą wydatkowały środki unijne w danym okresie programowania. Zasady gospodarowania i przeznaczenie środków UE wdrażanych w perspektywie finansowej 2014-2020 określa najważniejszy dokument programowy UE Strategia Europa 2020 na rzecz inteligentnego i zrównoważonego rozwoju sprzyjającego włączeniu społecznemu a na poziomie państwa członkowskiego umowa partnerstwa ${ }^{6}$. Zasady poprawnej gospodarki finan-

${ }^{3}$ Europejski Trybunał Obrachunkowy, Sprawozdanie specjalne nr 6/2019 - Zwalczanie nadużyć finansowych w wydatkowaniu środków UE w obszarze spójności, op.europa.eu/ (odczyt: 22.02.2020).

${ }^{4}$ Dz.U. z 2019 r., poz. 869 ze zm.

${ }^{5}$ Europejskie Funduszu Strukturalne i Inwestycyjne (EFSI) w perspektywie finansowej 2014-2020 obejmują 5 funduszy strukturalnych: Europejski Fundusz Rozwoju Regionalnego (EFRR), Europejski Fundusz Społeczny (EFS) oraz Fundusz Spójności (FS), Europejski Fundusz Rolnego Rozwoju Obszarów Wiejskich (EFRROW) oraz Europejski Fundusz Morski i Rybacki (EFMR).

${ }^{6}$ Programowanie perspektywy finansowej 2014-2020. Umowa Partnerstwa z 21 maja $2014 \mathrm{r}$., grudzień 2015 r. Dokument po zmianach wynikających z uzupełniania zapisów o EFRM oraz po negocjacjach programów operacyjnych, Ministerstwo Rozwoju, Warszawa 2015. 
sowej środkami UE określały przepisy rozporządzenia Rady (WE) nr 1083/200651 odnoszące się do poprzedniej perspektywy finansowej, jak również przepisy rozporządzenia Parlamentu Europejskiego i Rady (UE) nr 1303/2013 dotyczące okresu programowania 2014-2020. Rozporządzenia te obligują państwa członkowskie do zapobiegania nieprawidłowościom związanym z kwot nienależnie wypłaconymi, wykrywania oraz korygowania ich oraz śledzenia nieprawidłowości i dokonywania wymaganych korekt finansowych.

Postanowienia Traktatu o funkcjonowaniu Unii Europejskiej (TFUE) ${ }^{7}$ w art. 317 oraz rozporządzenia finansowego ${ }^{8} \mathrm{w}$ art. 36 wskazują, że Komisja Europejska wykonuje budżet UE w zgodzie z zasadą należytego zarządzania finansami oraz przy zapewnieniu skutecznej i efektywnej kontroli wewnętrznej, co obejmuje zapobieganie nadużyciom finansowym i innym nieprawidłowościom oraz ich wykrywanie, korygowanie i działania następcze. Komisja współpracuje w tym zakresie z państwami członkowskimi, które gromadzą i wydatkują do $80 \%$ budżetu UE. Artykuł 325 TFUE stanowi, że za zwalczanie nadużyć finansowych i wszelkich innych nielegalnych działań naruszających interesy finansowe UE odpowiadają wspólnie UE (reprezentowana przez Komisję Europejską) i państwa członkowskie. Obowiązek ten odnosi się do wszystkich programów w zakresie wydatków i przychodów UE oraz wszystkich obszarów polityki. Za wykrywanie nieprawidłowości w wydatkowaniu funduszy unijnych odpowiedzialne są głównie państwa członkowskie. Jeśli kwota, której dotyczą nadużycia, przekracza 10 tys. euro, są zobowiązane poinformować o tym Europejski Urząd ds. Zwalczania Nadużyć Finansowych - OLAF ${ }^{9}$

Przestępstwa przeciwko interesom finansowym UE zdefiniowane w Konwencji o ochronie interesów finansowych Wspólnot Europejskich wskazują, że są one skierowane przeciwko wydatkom (niewłaściwe wykorzystanie lub bezprawne zatrzymanie funduszy) i przeciwko dochodom (bezprawne uszczuplenie dochodów). Artykuł 1 pkt 1a konwencji określa, że oszustwem w odniesieniu do wydatków jest każde umyślne działanie lub zaniechanie działania dotyczące:

${ }^{7}$ Traktat o funkcjonowaniu Unii Europejskiej z Lizbony zmieniający Traktat o Unii Europejskiej i Traktat ustanawiający Wspólnotę Europejską podpisany w Lizbonie dnia 13 grudnia 2007 r. (Dz. Urz. UE C 306 z 17.12.2007).

${ }^{8}$ Rozporządzenie Parlamentu Europejskiego i Rady (UE, Euratom) 2018/1046 z dnia 18 lipca 2018 r. w sprawie zasad finansowych mających zastosowanie do budżetu ogólnego Unii, zmieniające rozporządzenia (UE) nr 1296/2013, (UE) nr 1301/2013, (UE) nr 1303/2013, (UE) nr 1304/2013, (UE) nr 1309/2013, (UE) nr 1316/2013, (UE) nr 223/2014 i (UE) nr 283/2014 oraz decyzję nr 541/2014/UE, a także uchylające rozporządzenie (UE, Euratom) nr 966/2012.

${ }^{9}$ Rozporządzenie 1303/2013, Wytyczne Komisji Europejskiej dla państw członkowskich i organów zarządzających programami w sprawie ryzyka nadużyć finansowych oraz skutecznych i proporcjonalnych środków zwalczania nadużyć finansowych z dnia 16 czerwca 2014 roku (EGESIF_14-021-00-16/06/2014), Ministerstwo Infrastruktury i Rozwoju, Wytyczne w zakresie sposobu korygowania i odzyskiwania nieprawidłowych wydatków oraz raportowania nieprawidłowości w ramach programów operacyjnych polityki spójności na lata 2014-2020 z dnia 20 lipca 2015 r., Ministerstwo Infrastruktury i Rozwoju. 
- wykorzystywania lub przedłożenia fałszywych, niekompletnych lub nieścisłych oświadczeń lub dokumentów, w wyniku czego zostały przekazane i zatrzymane nienależne fundusze pochodzące $\mathrm{z}$ ogólnego budżetu Wspólnoty Europejskiej (WE) lub z budżetów zarządzanych przez WE lub w ich imieniu,

- nieudostępnienia informacji powodującego brak realizacji określonego zobowiązania, powodującego ten sam skutek;

- niewłaściwego wykorzystania środków na inne cele aniżeli te, na które zostały one przyznane.

Jako oszustwa w odniesieniu do przychodów (art. 1 pkt b Konwencji) określone zostały jakiekolwiek umyślne działanie lub zaniechanie dotyczące:

- wykorzystania lub przedstawienia nieprawdziwych, niepoprawnych lub niepełnych oświadczeń lub dokumentów, które ma na celu bezprawne zmniejszenie środków budżetu ogólnego wspólnot europejskich lub budżetów zarządzanych przez lub w imieniu WE;

- nieujawnienia informacji z naruszeniem szczególnego obowiązku w tym samym celu;

- niewłaściwego wykorzystania korzyści uzyskanej zgodnie z prawem w tym samym celu.

Polska - jako strona konwencji - implementowała do ustawodawstwa krajowego opisane w tym dokumencie przestępstwa lub czyny i uznała je za ścigane na jej obszarze. Traktat Ustanawiający Wspólnotę Europejską ${ }^{10}$ (art. 280) nakłada na kraje członkowskie obowiązek ochrony wspólnotowych interesów finansowych i wymusza zapewnienie efektywnego poziomu ich zabezpieczenia. Zgodnie z tym przepisem państwa członkowskie podejmują takie same działania do walki $\mathrm{z}$ oszustwami godzącymi w interesy finansowe Wspólnoty, jakie stosują do walki $\mathrm{z}$ oszustwami godzącymi $\mathrm{w}$ ich własne interesy finansowe. Oznacza to, że państwa UE są zobligowane do zapewnienia skutecznej ochrony budżetu wspólnotowego na poziomie krajowym i ponoszą odpowiedzialność za wszelkie naruszenia interesów finansowych UE. Odpowiedzialność ta rozciąga się również na nieefektywność czy nieudolność działania instytucji krajowych w tym zakresie. Prawidłowa i skuteczna realizacja obowiązku wynikającego z art. 280 Traktatu Ustanawiającego Wspólnotę wymaga współpracy polskich resortów, służb i instytucji prawnie zobowiązanych do zwalczania przestępczości związanej z nadużyciami finansowymi oraz ochroną interesów finansowych Polski i UE. Zgodnie z decyzją Komisji Europejskiej z dnia 16 maja 2002 r. nowe kraje członkowskie - w tym Polska - utworzyły Jednostki ds. Koordynacji Przeciwdziałania Oszustwom (AFCOS). W Polsce jednostką AFCOS jest Wydział Ochrony Interesów Finansowych Unii Europejskiej znajdujący się w strukturze Departamentu Certyfikacji i Poświadczeń Środków z UE Ministerstwa Finansów, Inwestycji i Rozwoju. Skutkiem zobowiązań administracyjno-prawnych i przedakcesyjnych podjętych przez Polskę było powołanie Pełno-

\footnotetext{
${ }^{10}$ Traktat Ustanawiający Wspólnotę Europejską (TWE - Dz.Urz. UE 30.3.2010, C84/3).
} 
mocnika Rządu ds. Zwalczania Nieprawidłowości Finansowych na Szkodę RP lub UE oraz utworzenie Międzyresortowego Zespołu ds. Zwalczania Nieprawidłowości Finansowych na szkodę RP lub UE - GAFU (Genaral Anti-Fraud Unit). W skład zespołu wchodzą wyżsi rangą przedstawiciele MF, MSWiA, MON, ABW, Agencji Wywiadu, Komendy Głównej Policji oraz Komendy Głównej Straży Granicznej. W ramach swych zadań zespół koordynuje, planuje, monitoruje oraz kontroluje realizację wszystkich działań podejmowanych przez organy, które mają na celu zabezpieczenie interesów finansowych Polski i UE. Konsekwencjami ujawnionych nieprawidłowości jest zazwyczaj zwrot środków do budżetu UE, jak również sankcje finansowe. W latach 2013-2017 Komisja Europejska i państwa członkowskie zidentyfikowały ok. 4,1 tys. nieprawidłowości będących nadużyciami finansowymi na łączną kwotę ok. 1,5 mld euro (tab. 1). W łącznej kwocie zgłoszonych nadużyć finansowych ok. $73 \%$ nieprawidłowo wydatkowanych środków było związanych z polityką spójności UE. Nadużycia finansowe w obszarze Wspólnej Polityki Rolnej stanowiły ok. $350 \mathrm{mln}$ euro, tj. $24 \%$.

Tabela 1. Nieprawidłowości zgłoszone jako nadużycia finansowe w podziale na obszary polityki (lata 2013-2017)

\begin{tabular}{|l|c|c|c|c|}
\hline \multirow{2}{*}{ Obszary polityki } & \multicolumn{2}{|c|}{$\begin{array}{c}\text { Nieprawidłowości zgłoszone, } \\
\text { jako nadużycia finansowe }\end{array}$} & \multicolumn{2}{c|}{$\begin{array}{c}\text { Kwota środków, których dotyczyły } \\
\text { nadużycia }\end{array}$} \\
\cline { 2 - 5 } & liczba & $\%$ & w mln euro & $\%$ \\
\hline $\begin{array}{l}\text { Wspólna polityka } \\
\text { rolna }\end{array}$ & 2081 & 50 & 350,9 & 24 \\
\hline Polityka spójności & 1733 & 42 & 1087,4 & 73 \\
\hline Pozostałe & 339 & 8 & 50,3 & 3 \\
\hline Ogółem & 4153 & 100 & 1488,3 & 100 \\
\hline
\end{tabular}

Źródło: opracowanie własne na podstawie: Europejski Trybunał Obrachunkowy, Sprawozdanie specjalne nr 6/2019 - Zwalczanie nadużyć finansowych w wydatkowaniu środków UE w obszarze spójności, op.europa.eu/ (odczyt: 22.02.2020).

W wydatkowaniu środków UE w perspektywie finansowej 2007-2013 ${ }^{11}$ nieprawidłowości zgłoszone przez państwa członkowskie jako nadużycia finansowe dotyczyły $0,44 \%$ środków unijnych wypłaconych w obszarze polityki spójności. Wskaźnik ten, określany mianem „wskaźnika wykrytych nadużyć finansowych”, przyjmował bardzo różne wartości w zależności od państwa członkowskiego (rys. 1). W przypadku środków unijnych w obszarze spójności w całym okresie programowania 2007-2013 wahał się od 0\% do 2,1\%. Wskaźnik ten osiągnął zerowy poziom dla Luksemburga, Finlandii, Irlandii i Szwecji, natomiast najwyższy poziom na Słowacji. W Polsce wskaźnik ten wynosił $0,61 \%$ i był wyższy od średniego

\footnotetext{
${ }^{11}$ Dane według stanu na koniec 2017 r. - zamknięcia perspektywy finansowej 2007-2013.
} 


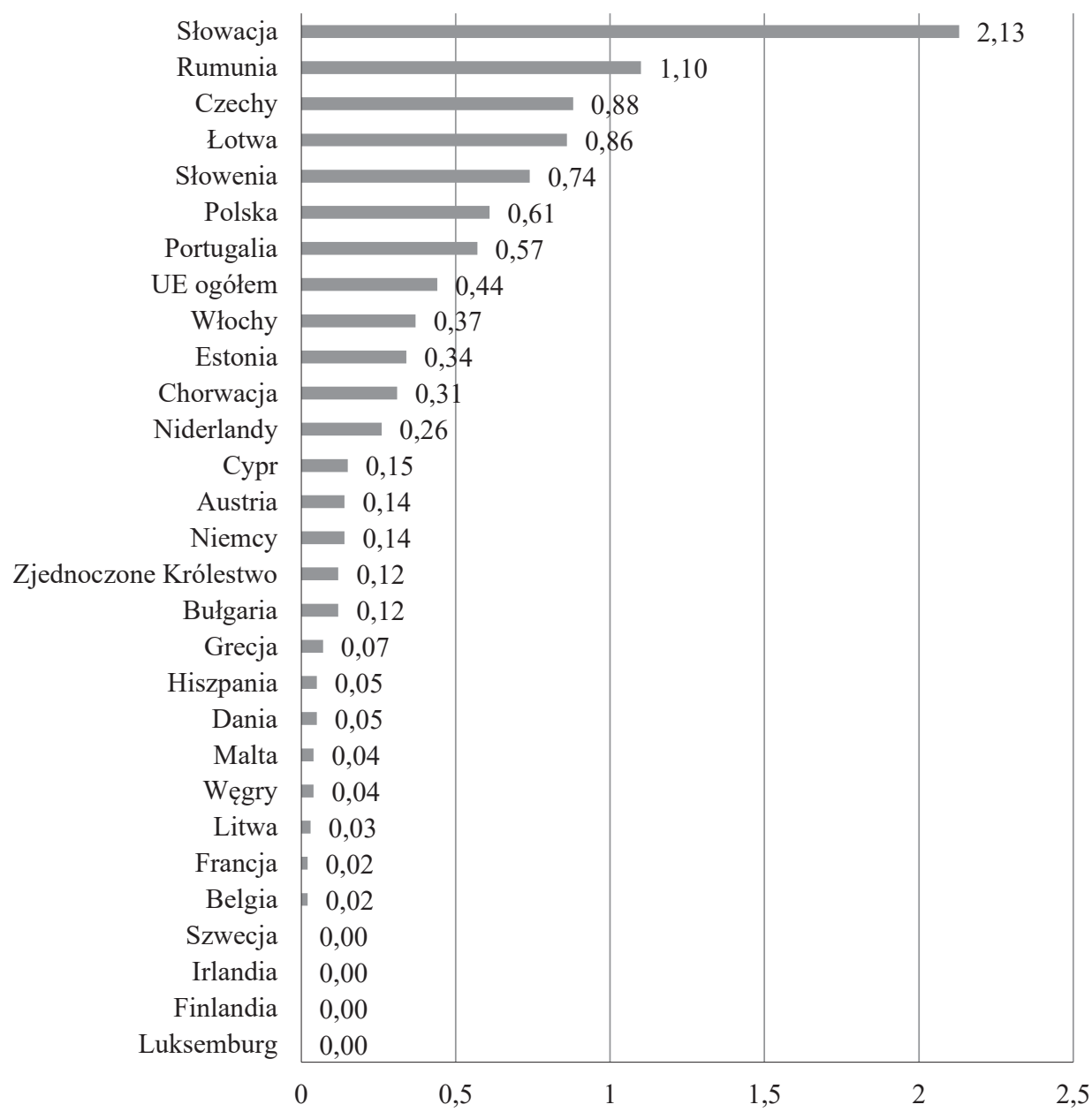

Rys. 1. Wykryte i zgłoszone przypadki nadużyć finansowych wyrażone jako odsetek środków w ramach polityki spójności otrzymanych przez państwa członkowskie UE w okresie programowania 2007-2013 (w \%)

Źródło: opracowanie własne na podstawie: Europejski Trybunał Obrachunkowy, Sprawozdanie specjalne nr 6/2019 - Zwalczanie nadużyć finansowych w wydatkowaniu środków UE w obszarze spójności, op.europa.eu/ (odczyt: 22.02.2020).

wskaźnika dla UE wynoszącego $0,44 \%$. Przeciętna wartość pojedynczej nieprawidłowości zgłoszonej jako nadużycie finansowe wynosiła 0,8 mln euro (rys. 1). Zdiagnozowaną ${ }^{12}$ przyczyną występowania różnic w skali omawianego niekorzystnego

${ }^{12}$ Sprawozdanie specjalne Europejskiego Trybunału Obrachunkowego - Zwalczanie nadużyć finansowych w wydatkowaniu środków UE - konieczne jest podjęcie działań (01/2019). 
zjawiska w poszczególnych krajach członkowskich UE były różne sposoby prowadzenia sprawozdawczości. Komisja Europejska stwierdza, że znaczące rozbieżności pomiędzy poszczególnymi państwami członkowskimi w zakresie zgłaszania nadużyć finansowych i nieprawidłowości mogą wynikać z różnej struktury krajowych systemów zwalczania nadużyć finansowych, a także z niezharmonizowanej sprawozdawczości. Niektóre państwa członkowskie kwalifikują nieprawidłowość jako popełnienie nadużycia dopiero po prawomocnym wyroku sądu, podczas gdy inne już na wcześniejszych etapach postępowania.

\section{Przesłanki i rodzaje występujących nadużyć finansowych środków UE w Polsce}

Kolejne perspektywy wdrażania środków unijnych wskazują, iż nawet najlepiej opracowane procedury kontroli nie wyeliminują ryzyka występowania nadużyć finansowych ${ }^{13}$. Potwierdzają to dane publikowane przez Ministerstwo Finansów pełniące funkcję Instytucji Płatniczej w zakresie środków z budżetu Unii Europejskiej $^{14}$. Największa liczba zgłoszonych do Komisji Europejskiej nieprawidłowości wskazywała na nadużycia finansowe w wykorzystaniu środków w ramach Europejskiego Funduszu Rolnego na rzecz Rozwoju Obszarów Wiejskich, natomiast najwyższa kwota dotyczyła Europejskiego Funduszu Rozwoju Regionalnego (tab. 1). Dla Komisji Europejskiej i państwa członkowskiego istotne jest, czy nieprawidłowość została wykryta przed wypłatą środków beneficjentowi czy też po dokonaniu płatności. Ponad $80 \%$ stwierdzonych nieprawidłowości wykryte zostało przed dokonaniem płatności. W celu zminimalizowania ryzyka nieprawidłowego wydatkowania środków z funduszy strukturalnych i Funduszu Spójności pomocne może okazać się przeanalizowanie rodzajów nieprawidłowości, które odzwierciedlają naruszenie przepisów prawa. Najczęściej występującą nieprawidłowością (rys. 2) było niewłaściwe stosowanie przepisów ustawy z dnia 29 stycznia 2004 r. Prawo zamówień publicznych ${ }^{15}$, a w szczególności dotyczących:

- zasad konkurencji i upowszechniania informacji o zamówieniu,

- działań związanych z przygotowaniem dokumentacji (np. brak dokumentacji projektowej w chwili zamieszczenia ogłoszenia o zamówieniu publicznym,

${ }^{13}$ A. Walenia (2017), Mechanizmy kontroli instrumentów prawno-finansowych polityki spójności UE w perspektywie finansowej 2014-2020, Difin, Warszawa, s. 156-160.

${ }^{14}$ Raporty z monitoringu i kontroli środków Unii Europejskiej, Ministerstwo Finansów, Warszawa 2019. Sprawozdania z monitoringu środków z budżetu Unii Europejskiej wskazują, że w okresie od 2007 r. do końca 2017 r. wykrytych zostało 613 przypadków nieprawidłowości w zakresie wdrażania funduszy strukturalnych oraz Funduszu Spójności, podlegających równocześnie obowiązkowi raportowania do Komisji Europejskiej. Państwo członkowskie ma obowiązek informowania Komisji Europejskiej, jeżeli nieprawidłowości przekraczają określone progi kwotowe; do dnia 31.12.2005 r. obowiązywał próg 4000 euro, a w poprzedniej i bieżącej perspektywie finansowej kwota 10000 euro.

${ }^{15}$ Dz.U. z 2019 r., poz. 1843 ze zm. 
nieprzekazanie oferentom robót Specyfikacji Istotnych Warunków Zamówienia w terminie określonym w ustawie),

- wyboru najkorzystniejszej oferty.

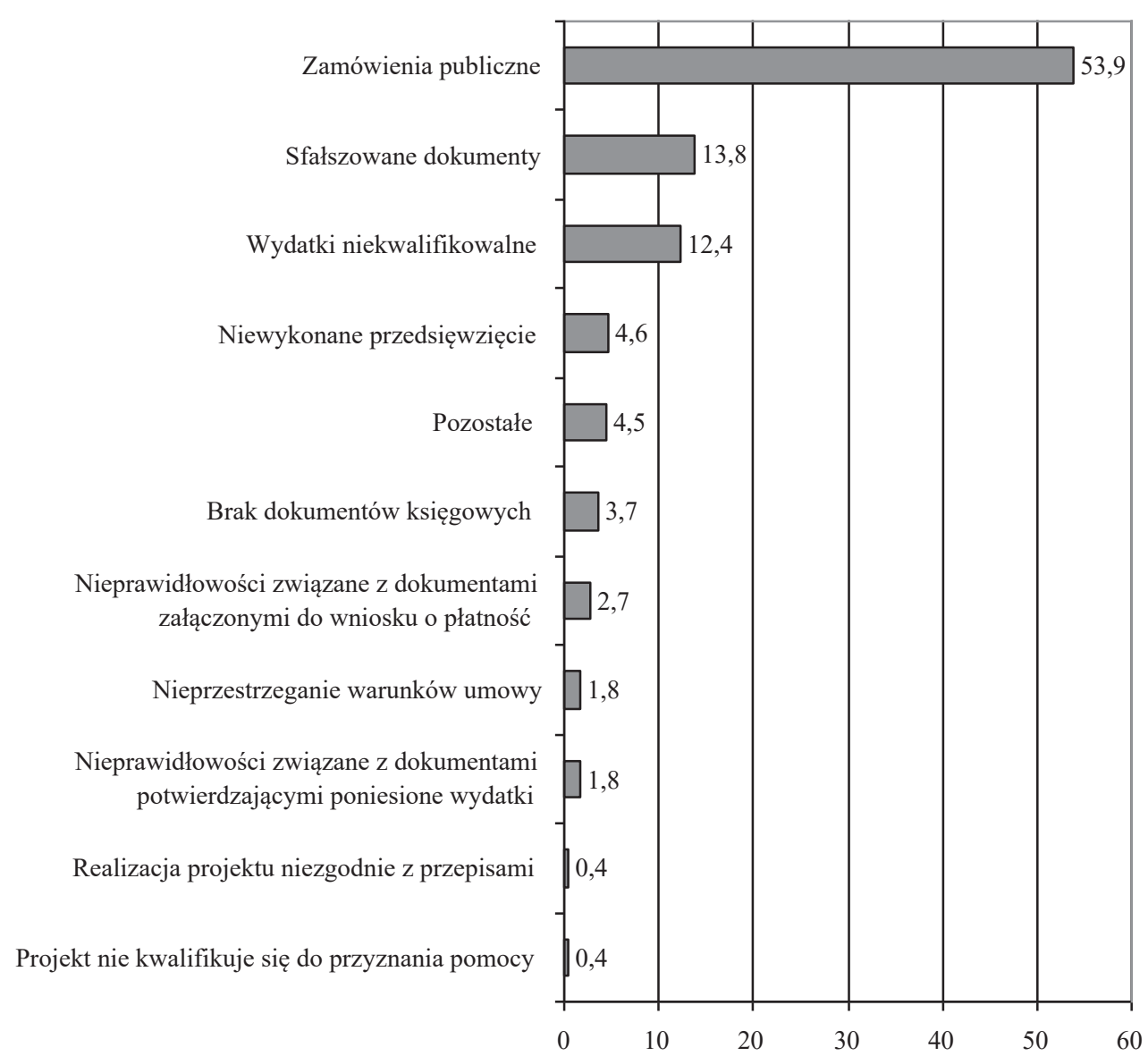

Rys. 2. Rodzaje zgłoszonych do Komisji Europejskiej nieprawidłowości dotyczących środków UE (w \%) Źródło: Dane Ministerstwo Finansów, Departament Certyfikacji i Poświadczeń Środków z UE (raporty i opracowania 2019).

Występującym nadużyciem finansowym było fałszowanie dokumentów - działanie takie występowało w odniesieniu do wniosków o dofinansowanie projektu, w przypadku których beneficjenci przedstawiali nieprawdziwe dane lub załączali sfałszowane dokumenty uzupełniające (różnego typu oświadczenia, zaświadczenia). Tego typu działania traktowane są jako podejrzenia popełnienia oszustwa na szkodę 
budżetu UE ${ }^{16}$. Jeśli chodzi o wydatki niekwalifikowalne - najczęściej wykrywane są przypadki finansowania przez beneficjentów działań, które nie są związane z realizacją przedsięwzięcia oraz nie zostały określone w umowie o dofinansowanie. W przypadku stwierdzenia tego typu nieprawidłowości beneficjenci nie mogą liczyć na refundację wydatków ze środków unijnych. Natomiast w sytuacji ostatecznego dokonania wszystkich płatności na rzecz beneficjenta podejmowane są czynności mające na celu egzekucję nieprawidłowo sfinansowanych działań. Występującą nieprawidłowością była także niepełna realizacja planowanych zadań w ramach projektu, np. zakupu produktów lub wykonania robót. Sytuacja taka może zaistnieć, jeżeli wskaźniki produktu określone we wniosku o dofinansowanie projektu i w sprawozdaniach z realizacji projektu nie są zgodne z rzeczywiście wykonanymi robotami lub dostarczonymi usługami. Takie przypadki traktowane są jako potwierdzenie przez beneficjenta nieprawdziwych informacji i w konsekwencji uznawane są za działania mające na celu wyłudzenie środków UE, a więc popełnienie przestępstwa.

W procesie realizacji przedsięwzięć współfinansowanych ze środków UE można wskazać następujące przyczyny powstawania nieprawidłowości:

- nieznajomość przepisów prawnych, a w szczególności przepisów prawa zamówień publicznych oraz dokumentów dotyczących wdrażania programu operacyjnego,

- nieprzestrzeganie przez beneficjentów zasad określonych w umowie o dofinansowanie,

- zmienność przepisów prawa,

- nierzetelność lub niedokładność przedkładanych przez beneficjenta dokumentów, sporządzanie nierzetelnych sprawozdań z realizacji projektu oraz wniosków o płatność (brak dokumentacji, błędy rachunkowe).

Dane Ministerstwa Finansów pełniącego funkcję instytucji płatniczej w procesie zarządzania środkami UE (rys. 3) potwierdzały, że najbardziej skutecznymi sposobami wykrywania nieprawidłowości w gospodarowaniu funduszami unijnymi są: kontrola na miejscu oraz wstępne czynności sprawdzające, tj. weryfikacja wniosków o dofinansowanie projektu oraz wniosków o płatność. Materiał empiryczny potwierdza, iż ponad $80 \%$ przypadków niewłaściwego wydatkowania środków unijnych jest wykrywane przez instytucje uczestniczące we wdrażaniu programów operacyjnych, tj. instytucje zarządzające, instytucje pośredniczące oraz instytucje wdrażające. System kontrolny państwa jest mało skuteczny w tym zakresie - organy kontroli państwa (kontrola KAS, NIK, RIO, Prezes Urzędu Zamówień Publicznych) wykrywają zaledwie $4 \%$ nieprawidłowości.

Wykrycie nieprawidłowości przez instytucje kontrolujące powoduje zastosowanie sankcji określonych w przepisach ustawy o finansach publicznych oraz umowie o dofinansowanie projektu (np. zwrot dotychczas otrzymanych środków, wyklucze-

${ }^{16}$ P. Makuch (2015), Organizacja systemu nakładania korekt finansowych oraz postepowanie $z$ nieprawidlowościami stwierdzonymi w toku kontroli procedur zawierania umów w NFOŚiGW, Departament Kontroli Zamówień Publicznych NFOŚiGW, Warszawa, s. 78-79. 
nie z otrzymania dofinansowania) ${ }^{17}$. Ponadto państwo członkowskie jest zobowiązane do poinformowania Komisji Europejskiej (Europejskiego Urzędu ds. Zwalczania Nadużyć Finansowych - OLAF) o występowaniu nieprawidłowości w realizacji projektu oraz o podmiotach, których działania doprowadziły do niewłaściwego wydatkowania środków unijnych.

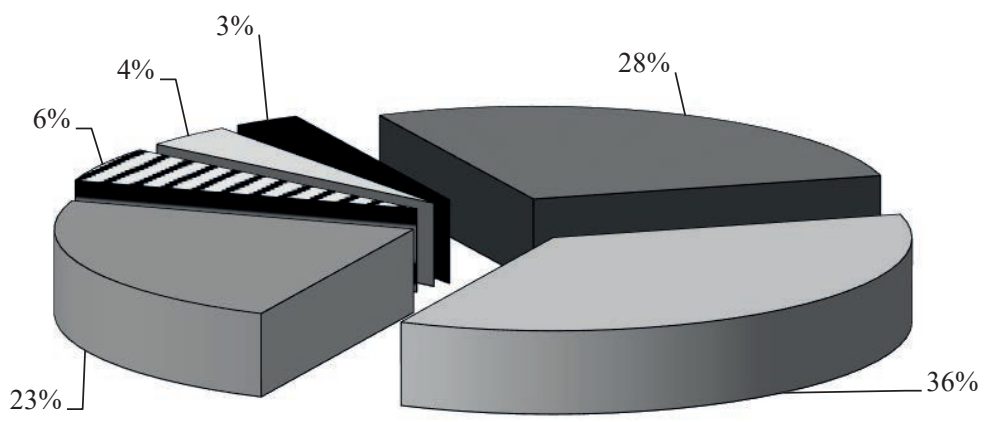

$\begin{array}{ll}\square \text { Kontrola dokumentów } & \square \text { Inne } \\ \square \text { Kontrola podatkowa, skarbowa } & \square \text { Kontrola ex-post } \\ \square \text { Wstępne czynności sprawdzające } & \square \text { Kontrola na miejscu }\end{array}$

Rys. 3. Metody wykrywania nieprawidłowości w wykorzystaniu środków z budżetu UE (\% poszczególnych metod służących do wskazania ogólnej kwoty nieprawidłowości w Polsce)

Źródło: Dane Ministerstwa Finansów, Departament Certyfikacji i Poświadczeń Środków z UE (raporty i opracowania 2019).

Ze względu na fakt, iż tego typu nieprawidłowość stanowi przestępstwo, stosowane jest także odwołanie się do polskich przepisów prawa karnego. Pomimo że kodeks karny ${ }^{18}$ nie wskazuje bezpośrednio, jakie działania stanowią przestępstwo na szkodę unijnego budżetu, dotychczasowe doświadczenia organów ścigania, tj. policji i prokuratury, wskazują, że najczęściej naruszane są przepisy kodeksu karnego dotyczące:

- przedkładania podrobionego, przerobionego, poświadczającego nieprawdę albo nierzetelnego dokumentu albo nierzetelnego, pisemnego oświadczenia dotyczącego okoliczności o istotnym znaczeniu w celu uzyskania dotacji (także subwencji, pożyczki) od banku lub jednostki organizacyjnej prowadzącej podobną działalność gospodarczą na podstawie ustawy albo od organu lub instytucji dysponujących środkami publicznymi (art. 297 §1) - przestępstwo to jest zagrożone karą pozbawienia wolności od 3 miesięcy do 5 lat;

${ }^{17}$ P. Wiśniewski (2013), Korekty finansowe za naruszenia przepisów o zamówieniach publicznych, Monitor Zamówień Publicznych, nr 2, s. 189-190.

${ }^{18}$ Ustawa z dnia 6 czerwca 1997 r. Kodeks karny (t.j. Dz.U z 2020 r., poz. 1444 ze zm.). 
- podrabiania lub przerabiania dokumentu lub używania takiego dokumentu jako autentycznego - przestępstwo to zagrożone jest karą grzywny oraz karą ograniczenia wolności albo pozbawienia wolności od 3 miesięcy do 5 lat;

- doprowadzenia innej osoby do niekorzystnego rozporządzenia własnym lub cudzym mieniem za pomocą wprowadzenia jej w błąd albo wykorzystania błędu lub niezdolności do należytego pojmowania przedsiębranego działania w celu osiągnięcia korzyści majątkowej - przestępstwo to zagrożone jest karą pozbawienia wolności od 6 miesięcy do 8 lat.

$\mathrm{W}$ praktyce najczęściej popełnianym nadużyciem finansowym jest naruszenie przepisów ustawy Prawo zamówień publicznych oraz fałszowanie dokumentów lub składanie oświadczeń niezgodnych z prawdą. Źródłem oszustw finansowych mogą być nie tylko działania beneficjentów, ale także osób odpowiedzialnych za podejmowanie decyzji w instytucjach uczestniczących we wdrażaniu programu operacyjnego. Za nadużycia finansowe mogą być uznawane także takie działania, jak: podjęcie decyzji o dofinansowaniu projektu, który nie spełnia wymogów formalno-prawnych, niedokładne przeprowadzenie wymaganej weryfikacji wniosku o dofinansowanie projektu lub wniosku o płatność, dokonanie płatności pomimo niezrealizowania przez beneficjenta kolejnego etapu przedsięwzięcia ${ }^{19}$. Informacje o wszelkich podejrzeniach nadużycia przekazywane powinny być policji oraz prokuraturze i wówczas stają się przedmiotem postępowań prowadzonych przez właściwe organy ścigania.

W przypadku wykrycia nieprawidłowości, w tym w szczególności oszustwa finansowego, beneficjenci muszą się liczyć z nałożeniem sankcji. Oczywiście dotkliwość i rodzaj kary są uzależnione od wagi nieprawidłowości oraz jej skutków dla dalszej realizacji projektu. Przepisy prawne związane z wykrywaniem nieprawidłowości w wykorzystaniu środków unijnych wskazują następujące rodzaje sankcji stosowanych wobec beneficjentów niewłaściwie wydatkujących środki unijne:

- kara pozbawienia wolności - jest stosowana w przypadku udowodnienia beneficjentowi naruszenia przepisów kodeksu karnego. W zależności od kwalifikacji czynu beneficjent może zostać skazany na karę pozbawienia wolności w zawieszeniu (np. art. 270, art. 280 oraz art. 297 kodeksu karnego);

- zwrot wszystkich środków dofinansowania - sankcja ta jest stosowana w przypadku niezrealizowania przedsięwzięcia zgodnie z zapisami umowy o dofinansowanie projektu i zależy od rodzaju stwierdzonych nieprawidłowości, np. jeżeli instytucje kontrolne wykryją, iż beneficjent złożył fałszywe dokumenty, które były podstawą przyznania dofinansowania, wówczas z pewnością będzie musiał zwrócić całą wysokość otrzymanego dotychczas dofinansowania wraz z odsetkami. Całkowity zwrot środków jest najczęściej orzekany w przypadku skazania beneficjenta za przestępstwo (nadużycie finansowe) naruszające interesy finansowe UE;

- wykluczenie z możliwości otrzymania dofinansowania w przyszłości - sytuacja taka występuje w przypadku wykorzystania przez beneficjenta środków

${ }^{19}$ A. Walenia (2017), wyd. cyt., s. 195-198. 
niezgodnie z przeznaczeniem i tym samym niezrealizowania pełnego zakresu rzeczowego projektu. Zgodnie z ustawą o finansach publicznych beneficjent nie będzie mógł otrzymać dofinansowania ze środków unijnych przez 3 lata;

- zwrot części zrefundowanych środków w związku z uznaniem niektórych wydatków za nieprawidłowe - sankcja ta jest stosowana w odniesieniu do projektów zarówno już zakończonych, jak i będących w trakcie realizacji. W przypadku wykrycia nieprawidłowości w działaniach już zrefundowanych ze środków unijnych beneficjent jest zobowiązany do ich zwrotu. W przypadku odmowy ze strony beneficjenta instytucja wypłacająca środki jest zobligowana do zastosowania innego rodzaju sankcji, tj. potrącenia środków z kolejnej transzy refundacji (projekt w trakcie realizacji) lub wszczęcia postępowania windykacyjnego (projekt zakończony);

- odmowa refundacji wydatków uznanych za nieprawidłowe - takie działanie występuje w przypadku, gdy nieprawidłowość zostanie wykryta w odniesieniu do wydatków beneficjenta, które nie zostały mu dotychczas zrefundowane;

- korekta środków uznanych za nieprawidłowe z kolejnej transzy refundacji - dotyczy przypadku, gdy projekt jest w trakcie realizacji i beneficjent nie dokonał jego rozliczenia. Wówczas można oczekiwać, iż określone przez instytucję kontrolną nieprawidłowo wykorzystane środki zostaną beneficjentowi potrącone z kolejnej transzy refundacji;

- naprawienie szkody - sankcja ta polega na konieczności ponownego przeprowadzenia działań, które zostały uznane za nieprawidłowe, ale nie mają istotnych konsekwencji finansowych dla realizacji projektu. Z taką sytuacją możemy się spotkać, jeżeli został popełniony błąd przy składaniu wniosku o płatność lub w trakcie procedur przetargowych.

Przedstawione sankcje najczęściej nie występują pojedynczo, ale są stosowane jednocześnie, np. zwrot całego dofinansowania oraz wykluczenie z możliwości otrzymania środków unijnych w przyszłości. Konsekwencje wykrycia nieprawidłowości dotyczą nie tylko beneficjenta, ale także państwa członkowskiego. Komisja Europejska może zażądać od państwa członkowskiego zwrotu środków unijnych, które zostały nieprawidłowo wykorzystane w ramach poszczególnych programów operacyjnych lub inicjatyw wspólnotowych. Decyzja Komisji Europejskiej o zwrocie środków może być spowodowana dużą liczbą wykrywanych nieprawidłowości lub brakiem dostatecznych działań ze strony państwa członkowskiego w celu odzyskania od beneficjenta niewłaściwie wydatkowanych kwot.

\section{Zakończenie}

Konstatując, należy stwierdzić, że problematyka nadużyć finansowych związanych z realizacją projektów współfinansowanych ze środków unijnych należy do istotnych zagadnień prawnych i organizacyjnych obowiązujących w państwach członkowskich i w UE. Mając na względzie, iż środki unijne przeznaczone dla Polski 
w perspektywie finansowej 2007-2013 zostały już wykorzystane, a aktualnie wydatkowane są fundusze z nowej perspektywy, należy podkreślić, że ukazanie problematyki nadużyć finansowych $\mathrm{w}$ poprzednim okresie programowania ma istotne znaczenie z praktycznego punktu widzenia. Interesy finansowe UE pozostają w bezpośrednim związku z interesami państw członkowskich i narażone są na ciągłe ryzyko związane z różnymi formami nadużyć finansowych i innymi działaniami niezgodnymi z prawem, które wywierają szkodliwy wpływ na przychody i wydatki budżetu ogólnego UE. Dlatego też aby przeciwdziałać takim niepożądanym praktykom, wprowadzono wiele regulacji prawnych i opracowanych zostało wiele procedur, które mają ograniczać i zniwelować skutki występujących nieprawidłowości. W Polsce w związku z implementacją prawa UE określone zostały regulacje prawne służące ochronie środków unijnych, a tym samym interesów budżetowych UE. Pomimo szeroko określonych uregulowań prawnych i organizacyjnych przeciwdziałających nadużyciom finansowym ze środków UE w Polsce zgłoszone i wykryte nadużycia finansowe stanowiły $0,61 \%$ środków przekazanych przez Komisję Europejską z przeznaczeniem na politykę spójności.

\section{Literatura}

Dzierżanowski W. (2011), Korekty finansowe jako element systemu kontroli wydatkowania środków europejskich, Zamówienia Publiczne. Doradca, nr 10, s. 5-6.

Karwatowicz G., Zawiślańska A. (2013), Korekty finansowe za naruszenie prawa zamówień publicznych $w$ projektach unijnych, Wyd. PRESSCOM, Wrocław, s. 67-69.

Krzykowski P. (2013), Zasady wymierzania korekt finansowych na projekty wspótfinansowane ze środków UE za naruszenia prawa zamówień publicznych przez jednostki samorząu terytorialnego i ich wplyw na zrównoważony rozwój społeczno-gospodarczy regionów, Journal of Modern Science, $\mathrm{nr}$ 1, s. 124-130.

Lamch-Rejowska M., Laszczyński Ł. (2012), Prawo zamówień publicznych. Praktyczny poradnik dla zamawiajacych $i$ wykonawców, LEX.

Łacny J. (2003), Ochrona interesów finansowych UE - działalność Europejskiego Biura ds. Zwalczania Oszustw (OLAF), Przegląd Prawa Europejskiego, nr 2, s. 56-57.

Łacny J. (2010), Ochrona interesów finansowych Unii Europejskiej w dziedzinie polityki spójności. Wyd. Wolters Kluwer Polska, Warszawa, s. 105-106.

Łacny J. (2012), Komentarz do art. 325 Traktatu o funkcjonowaniu Unii Europejskiej, [w:] Traktat o funkcjonowaniu Unii Europejskiej. Komentarz, t. III: Art. 223-358, red. A. Wrobel i in., WKP, LEX.

Makuch P. (2015), Organizacja systemu naktadania korekt finansowych oraz postępowanie z nieprawidłowościami stwierdzonymi w toku kontroli procedur zawierania umów w NFOŚiGW, Departament Kontroli Zamówień Publicznych NFOŚiGW, Warszawa, s. 78-79.

Mazurek G. (2015), Odpowiedzialność karna w zamówieniach publicznych. Komentarz praktyczny, ABC nr 98627, Lex dla Samorządu Terytorialnego.

Poździk R. (2014), Zasady wdrażania funduszy unijnych w latach 2014-2020, Europejski Przegląd Sądowy, nr 12, s. 89-90.

Ricketts A., Galster J. (2008), Head angle and elevation in classroom environments: Implications for amplification, Journal of Speech, Language, and Hearing Research, 51.2, s. 123-136. 
Moor de S. (2005), Transnational Investigations and the Judicial Follow-Up to the OLAF Inspection Reports under the Existing Cooperation Instruments, [w:] J.A.E. Vervaele (red.), European Evidence Warrant. Transnational Judicial Inquries in the EU, Antwerpen - Intersentia.

Suchecka A. (2012), Korekta finansowa i podstawy jej wymiaru, Przetargi Publiczne, nr 1, s. 57-58.

Szostak R. (2011), Charakter prawny korekt finansowych, Zamówienia Publiczne. Doradca, nr 10, s. $98-100$.

Walenia A. (2017), Mechanizmy kontroli instrumentów prawno-finansowych polityki spójności UE w perspektywie finansowej 2014-2020, Difin, Warszawa, s. 156-160.

Wiatrowski P. (2009), Zwalczanie korupcji oraz nadużý finansowych w UE w świetle prawa wspólnotowego, Zeszyty Naukowe Uniwersytetu Ekonomicznego w Krakowie, nr 809, s. 134-135.

Wiśniewski P. (2013), Korekty finansowe za naruszenia przepisów o zamówieniach publicznych, Monitor Zamówień Publicznych, nr 2, s. 189-190.

Zawłocka-Turno A. (2012), Zmowa przetargowa czy działanie zgodne z prawem? Problemy na styku prawa konkurencji i prawa zamówień publicznych, Kwartalnik Antymonopolowy i Regulacyjny, nr 4, s. 145-146.

\title{
FRAUD IN THE AREA OF COHESION POLICY VERSUS PROTECTION OF THE BUDGETARY INTERESTS OF THE EUROPEAN UNION
}

\begin{abstract}
The purpose of the article is to analyse the fraud occurring in the process of using the resources from the EU budget intended for cohesion policy. The article presents the organisational and legal conditions implemented in the Member States and the European Union aimed at limiting the irregularities in using the EU resources. Fraud has a detrimental impact on the revenues and expenditure of the EU general budget, it may result in using these resources for other unjustifiable purposes, and therefore reduce the effectiveness of the EU activities in the specified areas. This phenomenon relates particularly to using the resources as part of the projects co-financed by the EU funds. The importance of this problem increases especially at the time of growing public finance deficit in the EU budget. Further prospects of implementing the EU resources indicate that even the most well-developed control procedures will not eliminate the risk of fraud occurrence. Based on empirical data, the extent and reasons for existing irregularities in using the EU resources intended for cohesion policy in Poland have been identified.
\end{abstract}

Keywords: cohesion policy, EU resources, fraud, EU financial interests. 